\title{
Effects of an automatic milking system on milk yield and quality of Mediterranean buffaloes
}

\author{
M. Sannino, ${ }^{*}{ }^{1}$ S. Faugno, ${ }^{*}$ M. Crimaldi, ${ }^{*}$ A. Di Francia, ${ }^{*}$ L. Ardito, ${ }^{*}$ F. Serrapica, ${ }^{*}$ and F. Masucci \\ *Dipartimento di Agraria, Università degli Studi di Napoli Federico II, via Università 100, 80055 Portici, NA, Italy \\ †Dipartimento di Agricoltura, Foreste, Natura e Energia (DAFNE), Università della Tuscia, 01100 Viterbo, Italy
}

\begin{abstract}
A study was carried out to evaluate the effects of an automatic milking system (AMS) on milk yield and composition of buffalo (Mediterranean-type Bubalus bubalis) cows. Performed from January 2015 to December 2015 in an organic buffalo dairy farm equipped with both a traditional tandem milking parlor and an AMS, the study involved 90 primiparous buffaloes randomly allotted to a tandem or AMS group from 5 to $10 \mathrm{~d}$ of lactation onward. Number of milkings per day and daily milk yield of each cow were recorded, and individual milk sampling was carried out twice a month. Compared with the tandem, the AMS group showed significantly higher daily milk yield and persistence of lactation. Use of the AMS resulted in higher protein and casein contents, and lower somatic cell and total bacterial counts, whereas fat, freezing point, and $\mathrm{pH}$ were unaffected by the system. We conclude that, in terms of milk yield and quality, automatic milking may be a suitable alternative to conventional milking for buffaloes.
\end{abstract}

Key words: automatic milking system, dairy buffalo, milk yield, milk quality

\section{INTRODUCTION}

In Italy, water buffalo (Bubalus bubalis) dairy farming is a traditional zootechnic activity almost exclusively focusing on mozzarella cheese production (Masucci et al., 2016). Although buffalo farming has changed substantially in recent decades, undergoing rapid intensification of rearing techniques (Napolitano et al., 2004; Masucci et al., 2011), the first automatic milking system (AMS) for buffaloes was only introduced in 2008 in an organic farm in southern Italy. At present, the number of AMS for buffaloes is still very low, mainly due to concerns about the adaptability of buffalo cows

Received November 20, 2017.

Accepted March 26, 2018.

${ }^{1}$ Corresponding author: maura.sannino@unina.it to robotic milking. Indeed, compared with dairy cows, buffaloes present delayed milk ejection due to a different mechanisms of milk ejection, mammary anatomy, and the internal arrangement of mammary tissue, as well as longer and thicker teats (Thomas et al., 2004; Borghese et al., 2007; Ambord et al., 2010). Whereas the use of AMS has been studied deeply in dairy cows (Jacobs and Siegford, 2012), to date, scientific research on Mediterranean buffaloes is still limited (Caria et al., 2014; Faugno et al., 2015; Tangorra et al., 2017). The most attractive aspect of an automatic system for a farmer may be relief from the milking routine (Jensen, 2004). Yet AMS can positively influence milk yield in both cows (Baines, 2002; de Koning et al., 2002; Wall and McFadden, 2007) and buffaloes (Faugno et al., 2015). On the other hand, beside the large initial investment, a drawback to implementing AMS is a potential lowering of milk quality (Rasmussen et al., 2002). To our best knowledge, no research is currently available on the effect of AMS on Mediterranean buffalo milk quality. Therefore, this study aimed to shed light on the influence of AMS on buffalo milk yield and quality in terms of major constituents (i.e., fat, protein, casein, and lactose), udder health and hygiene [i.e., SCC and total bacterial count (TBC)], $\mathrm{pH}$, and freezing point.

\section{MATERIALS AND METHODS}

\section{Study Site, Experimental Design, and Animal Management}

The study was carried out on an organic buffalo farm $\left(40^{\circ} 27^{\prime} \mathrm{N}, 15^{\circ} 01^{\prime} \mathrm{E}, 31 \mathrm{~m}\right.$ above sea level) in Campania, a region in southern Italy. The farm is equipped with both a traditional system and an AMS that was installed in 2008. In the traditional system, cows are housed in freestall barns and milked in a conventional tandem $(5+5)$ parlor. In the AMS, cows are placed in a stall divided into 4 sectors $(40 \times 32 \mathrm{~m})$, each provided with a robotic milking machine (De Laval Voluntary Milking System 2007, Tumba, Sweden) serving a freestall pen of 40 to 45 buffaloes. A selection gate between pen and milking robot allows cows to be milked if a minimum 
time interval of $7 \mathrm{~h}$ elapses between 2 consecutive milkings. Otherwise animals are redirected to the feeding area. Further details on housing, management, and milking systems are given elsewhere (Faugno et al., 2015).

The study period considered was from January 2015 to December 2015. Ninety lactating primiparous buffaloes at the beginning of lactation (5 to 10 DIM) were randomly allotted to 2 groups milked with either the traditional system (tandem group) or with the AMS (AMS group). For AMS buffaloes it was ascertained that udder and teat shape were suitable for the automatic system as observed in cows. Primiparous cows were chosen to avoid potentially confounding effects due to experience with previous milking systems and because they adapt to AMS more quickly than multiparous cows (Hopster et al., 2002; Jago and Kerrisk, 2011). The animals were housed in the same automatic sector (AMS group) or pen (tandem group) and were fed once a day (0730 to $0900 \mathrm{~h}$ ) the same TMR at $13 \%$ of CP (on a DM basis) and $5.9 \mathrm{MJ} / \mathrm{kg}$ of DM of energy. The ration was based on silages, commercial concentrates, hays, and mineral and vitamin mix. Cows were also given a concentrate supplement ranging from 3 to $5 \mathrm{~kg} / \mathrm{d}$ per animal, depending on individual milk yield. For the tandem group, supplement was fed in 2 equal meals at the 0500 and $1700 \mathrm{~h}$ milking, whereas for the AMS group, it was split into 2 or 3 equal meals depending on the expected number of milkings. The working parameters of milking equipment were identical for both systems (i.e., $42 \mathrm{kPa}$ vacuum, 60 cycles/ min pulsator rate, and $60 \%$ pulsator ratio).

The number of milkings per day, milk yield/milking, and milk yield per day of each cow were collected daily by the software incorporated in the system (AMS group) or by farm staff by means of recording jars (tandem group). Individual milk samples were collected twice a month at afternoon milking (tandem group) or by using automatic milk sampling units (AMS group). Samples $(100 \mathrm{~mL}$ with azidiol) were analyzed in the following $24 \mathrm{~h}$ for macro-components, SCC, pH, freezing point, and TBC by infrared analysis (Integrated Milk Testing Milkoscan FT 6000, Bactoscan 8000, Foss Electric, Hillerød, Denmark).

\section{Data Selection and Analysis}

Statistical analysis was performed by means of $\mathrm{R}$ Studio software (version 1.1.383). Before analysis, normality and homogeneity of variance of data were checked by using the Shapiro-Wilks test and Levene test. Value of SCC and TBC were log-transformed to base 10. Data from $10 \mathrm{~d}$ after calving until the end of lactation (i.e., milk yield $<1 \mathrm{~kg}$ ) were considered; for the AMS group, data relative to a milking gap $>24 \mathrm{~h}$ were discarded (Faugno et al., 2015).

Daily milk yield and number of milkings per day (for AMS group) of each cow were examined until d 270 of lactation (i.e., standard lactation length of buffaloes) and estimated by dividing the whole yield and total milkings by 270 . Real lactation length and daily milk yield were analyzed by 1-way ANOVA (tandem or AMS) using cow as the experimental unit.

For each group, persistence of lactation (i.e., the rate of milk yield decline after the lactation peak) was calculated from d 57 to 270 as the percentage ratio between average milk yield in a month and the average milk yield of the previous month. Analysis was carried out by 1-way ANOVA (tandem or AMS) with month of lactation as experimental unit.

The lactation curves of the tandem and AMS groups were compared on a daily basis by means of 1-way ANOVA with the milking system as the fixed effect.

Data on milk quality (i.e., macro-components, SCC, TBC, $\mathrm{pH}$, and freezing point) underwent ANOVA for repeated measures (mixed procedure) with the milking system as a nonrepeated factor and month of sampling and milking system $\times$ month of sampling as repeated factors. The cow variance was considered as random and used as the error term to test the main effect of the milking systems.

\section{RESULTS AND DISCUSSION}

The number of milkings per day for the AMS group was $2.5 \pm 0.24$. Higher daily milk yield $(P<0.001)$ and persistency of lactation $(P<0.05)$ were observed in AMS compared with the tandem group (Table 1). These results extend and confirm those of our previous work carried out on the same farm from January 2013 to May 2014 in which cows milked automatically showed higher milk production (Faugno et al., 2015). Moreover, our findings are in agreement with those of several studies on dairy cows (de Koning and $\mathrm{Ou}$ weltjes, 2000; Wagner-Storch and Palmer, 2003; Wade et al., 2004), even though others found no milk yield increase in primiparous cows (Abeni et al., 2005, 2008; Speroni et al., 2006). The yield increase with the AMS may be due to several factors, especially the increase in milkings per day compared with the conventional system (Jacobs and Siegford, 2012), and a higher lactation persistence leading to a more stable production until the end of the lactation (Stelwagen, 2001). These results and assumptions are confirmed by the different lactation curve shapes of the 2 groups (Figure 1). In particular, the AMS group showed a statistically higher milk yield before and immediately after the lactation peak, and from d 233 onward. 


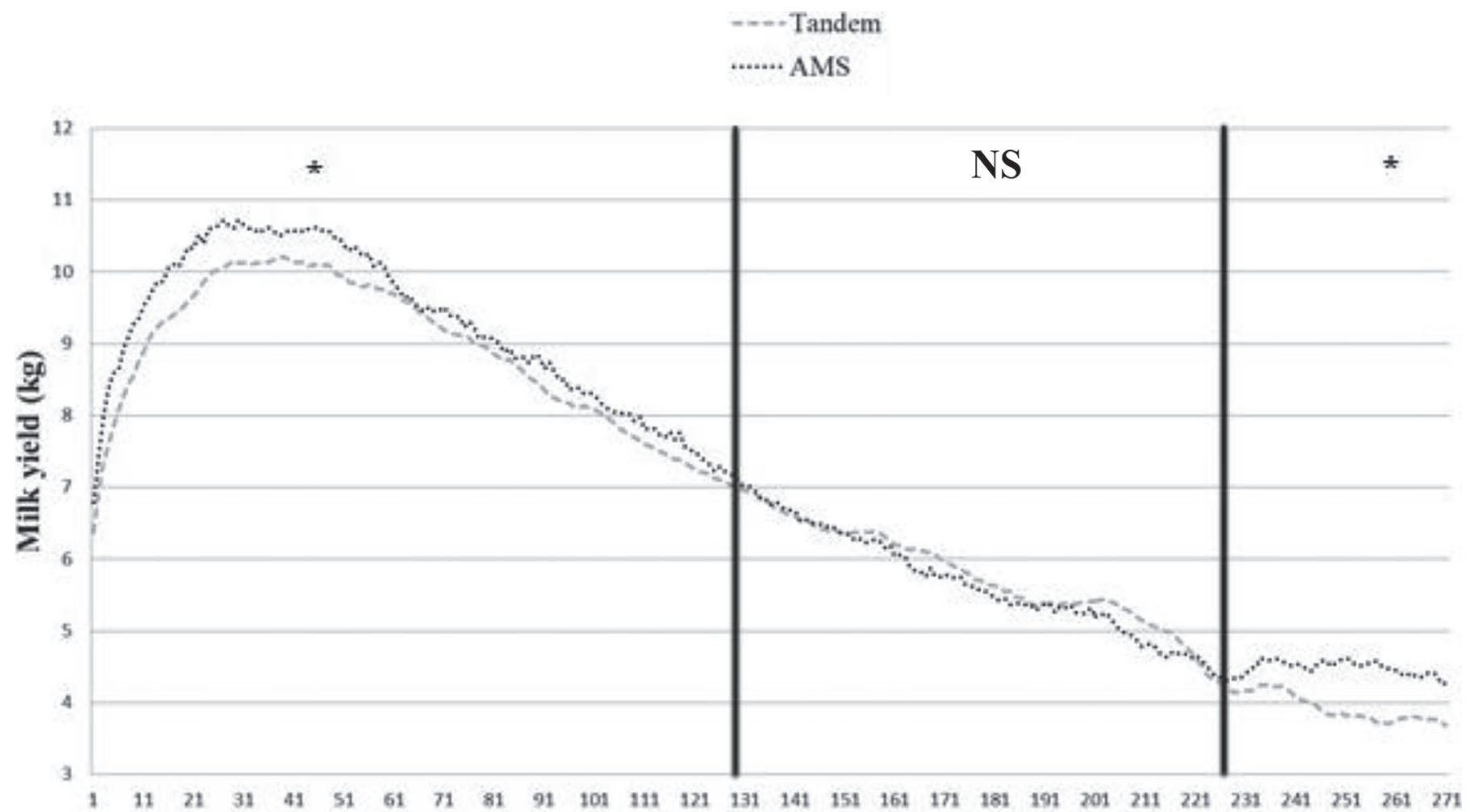

Days

Figure 1. Lactation curves from buffaloes milked by using an automatic milking system (AMS) and conventional tandem system (tandem). $* P<0.05$.

No differences were observed between groups in effective lactation length $(P>0.05)$. This may be due to the fact that both groups consisted of primiparous farmed in the same conditions. Indeed, parity, photoperiod, and climatic conditions, together with postpartum ovarian activity resumption, are the main factors influencing lactation length in Asiatic and Mediterranean buffaloes (Cady et al., 1983; Zicarelli, 1997; Hassan et al., 2017).

Milk characteristics of the 2 groups are shown in Table 2. As expected, the effect of month of sampling was often significant, and interactions milking system $\times$ month of sampling were negligible (data not shown).

No differences were found between AMS and tandem groups for fat and lactose contents, freezing point, and

Table 1. Milk yield, persistency, and length of lactation (LSM \pm SEM) from buffaloes milked by using an automatic milking system (AMS) and conventional tandem system (tandem)

\begin{tabular}{lcrrl}
\hline Item & AMS & Tandem & SEM & $P$-value \\
\hline Milk yield (kg/d) & 8.70 & 7.2 & 0.24 & 0.0001 \\
Persistence of lactation (\%) & 88.7 & 80.2 & 3.73 & 0.047 \\
Effective lactation length (d) & 321.6 & 323.0 & 9.91 & 0.9194 \\
\hline
\end{tabular}

$\mathrm{pH}(P>0.05)$. The AMS group showed statistically higher contents of both protein $(P<0.001)$ and casein $(P<0.001)$, and lower levels of SCC $(P<0.01)$ and TBC $(P<0.01)$. All values comply with legal limits imposed by the European Union Directives (46/92 and 71/94) for making raw-milk-based mozzarella cheese (Moroni et al., 2006; Guccione et al., 2014).

Table 2. Milk quality (LSM \pm SEM) from buffaloes milked by using an automatic milking system (AMS) and conventional tandem system (tandem)

\begin{tabular}{lcccc}
\hline Item & AMS & Tandem & SEM & $P$-value \\
\hline Macro-component $(\mathrm{g} / 100 \mathrm{~mL})$ & & & & \\
Fat & 8.38 & 8.48 & 0.047 & 0.1154 \\
Lactose & 4.70 & 4.73 & 0.070 & 0.3821 \\
$\quad$ Protein & 4.88 & 4.61 & 0.024 & 0.0001 \\
Casein & 3.95 & 3.78 & 0.019 & 0.0001 \\
Udder health and hygiene & & & & \\
SCC $/ \mathrm{mL}^{1}$ & 5.24 & 5.23 & 0.002 & 0.002 \\
TBC $/ \mathrm{mL}^{2}$ & 5.30 & 5.36 & 0.007 & 0.002 \\
pH & 6.73 & 6.74 & 0.020 & 0.3737 \\
Freezing point $\left({ }^{\circ} \mathrm{C}\right)$ & -0.535 & -0.533 & 0.001 & 0.3251 \\
\hline${ }^{1}$ Logarithmic SCC. & & & & \\
${ }^{2}$ Logarithmic total bacterial count. & & &
\end{tabular}


A large body of literature reports a deterioration of AMS milk quality in terms of fat, TBC, SCC, and freezing point. In general, the effect on milk fat is rather limited, and slight reductions can be observed due to an increment of milk yield (Klungel et al., 2000; Shoshani and Chaffer, 2001; Abeni et al., 2005). However, in our study such a dilution effect was not found.

As reported in cows, several studies show (see Rasmussen et al., 2002; de Koning et al., 2003) significant increases in milk SCC and TBC in relation to the use of an AMS, such that udder hygiene and health is thought to be at risk in farms using AMS due to incomplete teat and udder cleaning (Hovinen and Pyörälä, 2011). However, SCC and TBC increase mainly during the first months after the transition from a conventional system to an AMS, and both parameters decrease as time elapses from the farm's adoption of the AMS (Klungel et al., 2000; Helgren and Reinemann, 2006). Moreover, studies comparing conventional systems and AMS in the same farm failed to highlight any differences in milk SCC (Berglund et al., 2002; Abeni et al., 2005). The statistically lower levels of SCC and TBC of AMS milk we observed may be due to the fact that SCC can decrease when milkings exceed 2 per day (Klei et al., 1997; Smith et al., 2002; Dahl et al., 2004), due to inadequate udder cleaning in the conventional system, or both. However, the higher level of TBC in tandem system did not influence milk $\mathrm{pH}$.

The lack of statistical differences in milk freezing point between tandem and AMS groups might be viewed as further evidence of the good performance of the automatic milking process in the farm surveyed. Indeed, an incorrect cleaning procedure of the automatic equipment can leave residual water in tubes, connections, and tanks, leading to abnormal increases in the milk freezing point (Rasmussen et al., 2002).

The higher values observed for milk protein and casein in AMS group seem to be in contrast with the existing literature reporting no effect of AMS on milk protein (Abeni et al., 2005; Jacobs and Siegford, 2012). Further investigation on this issue is required to shed light on the findings.

\section{CONCLUSIONS}

Our results confirm that, compared with a conventional tandem system, AMS yield an increment in buffalo milk yield due to increased milking frequency and a greater persistence of lactation. In addition, we observed an improvement in milk quality in terms of higher protein and casein contents and better TBC and SCC values. Further research is required to find the origin of the higher protein and casein contents. Freezing point, $\mathrm{pH}$, fat, and lactose contents were not influenced by the system. Taken together with previous work on dairy cows, our findings suggest that, with regard to milk yield and quality, the AMS may be a suitable alternative to conventional milking, offering new management prospects for buffalo farming.

\section{ACKNOWLEDGMENTS}

The authors express their gratitude to Antonio Palmieri for allowing the study to be carried out on his farm. This research was supported by a grant from Dipartimento di Agricoltura, Foreste, Natura e Energia (DAFNE), Università della Tuscia (Viterbo, Italy).

\section{REFERENCES}

Abeni, F., L. Degano, F. Calza, R. Giangiacomo, and G. Pirlo. 2005 Milk quality and automatic milking: Fat globule size, natural creaming, and lipolysis. J. Dairy Sci. 88:3519-3529. https://doi .org/10.3168/jds.S0022-0302(05)73037-X.

Abeni, F., M. G. Terzano, M. Speroni, L. Migliorati, M. Capelletti, F. Calza, L. Bianchi, and G. Pirlo. 2008. Evaluation of milk enzymes and electrolytes, plasma metabolites, and oxidative status in twin cows milked in an automatic milking system or twice daily in a conventional milking parlor. J. Dairy Sci. 91:3372-3384. https:// doi.org/10.3168/jds.2008-1039.

Ambord, S., M. H. Stoffel, and R. M. Bruckmaier. 2010. Teat anatomy affects requirements for udder preparation in Mediterranean buffaloes. J. Dairy Res. 77:468-473. https://doi.org/10.1017/ S0022029910000518.

Baines, J. 2002. Managing the change to a robotic milking system. Pages III-9-III-17 in The First North American Conference on Robotic Milking, Wageningen Pers, Wageningen, the Netherlands.

Berglund, I., G. Pettersson, and K. Svennersten-Sjaunja. 2002. Automatic milking: Effects on somatic cell count and teat end-quality. Livest. Prod. Sci. 78:115-124. https://doi.org/10.1016/S0301 -6226(02)00090-8.

Borghese, A., M. Rasmussen, and C. S. Thomas. 2007. Milking management of dairy buffalo. Ital. J. Anim. Sci. 6:39-50. https://doi .org/10.4081/ijas.2007.s2.39.

Cady, R. A., S. K. Shah, E. C. Schermerhorn, and R. E. McDowell. 1983. Factors affecting performance of Nili-Ravi buffaloes in Pakistan. J. Dairy Sci. 66:578-586. https://doi.org/10.3168/jds.S0022 $-0302(83) 81828-1$.

Caria, M., F. M. Tangorra, S. Leonardi, V. Bronzo, L. Murgia, and A. Pazzona. 2014. Evaluation of the performance of the first automatic milking system for buffaloes. J. Dairy Sci. 97:1491-1498. https://doi.org/10.3168/jds.2013-7385.

Dahl, G. E., R. L. Wallace, R. D. Shanks, and D. Lueking. 2004. Hot topic: Effects of frequent milking in early lactation on milk yield and udder health. J. Dairy Sci. 87:882-885. https://doi.org/ 10.3168/jds.S0022-0302(04)73232-4.

de Koning, K., and W. Ouweltjes. 2000. Maximising the milking capacity of an automatic milking system. Pages 38-46 in Robotic Milking: Proceedings of the International Symposium, Lelystad, the Netherlands, August 17-19, 2000. Wageningen Pers, Wageningen, the Netherlands.

de Koning, K., B. Slaghuis, and Y. van der Vorst. 2003. Robotic milking and milk quality: Effects on bacterial counts, somatic cell counts, freezing point and free fatty acids. Ital. J. Anim. Sci. 2:291-299. https://doi.org/10.4081/ijas.2003.291.

de Koning, K., Y. Van der Vorst, and A. Meijering. 2002. Automatic milking experience and development in Europe. Pages I1-I11 in Proceedings of the First North American Conference on Robotic Milking, Toronto, Canada. Wageningen Pers, Wageningen, the Netherlands. 
Faugno, S., S. Pindozzi, C. Okello, and M. Sannino. 2015. Testing the application of an automatic milking system on buffalo (Bubalus bubalis). J. Agric. Eng. 46:13-18. https://doi.org/10.4081/jae.2015 437.

Guccione, J., A. Cosandey, A. Pesce, A. D. Loria, M. Pascale, D. Piantedosi, A. Steiner, H. U. Graber, and P. Ciaramella. 2014. Clinical outcomes and molecular genotyping of Staphylococcus aureus isolated from milk samples of dairy primiparous Mediterranean buffaloes (Bubalus bubalis). J. Dairy Sci. 97:7606-7613. https://doi .org/10.3168/jds.2014-8455.

Hassan, F. A. M., M. A. Ali, and M. S. El-Tarabany. 2017. Economic impacts of calving season and parity on reproduction and production traits of buffaloes in the sub-tropics. Environ. Sci. Pollut. Res. Int. 24:10258-10266. https://doi.org/10.1007/s11356-017-8686-1.

Helgren, J. M., and D. J. Reinemann. 2006. Survey of milk quality on U.S. dairy farms utilizing automatic milking systems. Trans. ASABE 49:551-556. https://doi.org/10.13031/2013.20398.

Hopster, H., R. M. Bruckmaier, J. T. N. Van der Werf, S. M. Korte, J Macuhova, G. Korte-Bouws, and C. G. van Reenen. 2002. Stress responses during milking; comparing conventional and automatic milking in primiparous dairy cows. J. Dairy Sci. 85:3206-3216. https://doi.org/10.3168/jds.S0022-0302(02)74409-3.

Hovinen, M., and S. Pyörälä. 2011. Invited review: Udder health of dairy cows in automatic milking. J. Dairy Sci. 94:547-562. https:// doi.org/10.3168/jds.2010-3556.

Jacobs, J. A., and J. M. Siegford. 2012. Invited review: The impact of automatic milking systems on dairy cow management, behavior, health, and welfare. J. Dairy Sci. 95:2227-2247. https://doi.org/ 10.3168/jds.2011-4943.

Jago, J., and K. Kerrisk. 2011. Training methods for introducing cows to a pasture-based automatic milking system. Appl. Anim. Behav. Sci. 131:79-85. https://doi.org/10.1016/j.applanim.2011.02.002.

Jensen, T. 2004. Expectations of automatic milking and the realized socio-economic effects. Pages 78-79 in Automatic Milking-A Better Understanding. A. Meijering, H. Hogeveen, and C. J. A M. de Koning, ed. Wageningen Academic Publishers, Wageningen, the Netherlands.

Klei, L. R., J. M. Lynch, D. M. Barbano, P. A. Oltenacu, A. J. Lednor, and D. K. Bandler. 1997. Influence of milking three times a day on milk quality. J. Dairy Sci. 80:427-436. https://doi.org/10.3168/jds .S0022-0302(97)75954-X.

Klungel, G. H., B. A. Slaghuis, and H. Hogeveen. 2000. The effect of the introduction of automatic milking systems on milk quality. J. Dairy Sci. 83:1998-2003. https://doi.org/10.3168/jds.S0022 -0302(00)75077-6.

Masucci, F., G. De Rosa, F. Grasso, F. Napolitano, G. Esposito, and A. Di Francia. 2011. Performance and immune response of buffalo calves supplemented with probiotic. Livest. Sci. 137:24-30. https://doi.org/10.1016/j.livsci.2010.09.019.

Masucci, F., G. D. Rosa, C. M. A. Barone, F. Napolitano, F. Grasso, P. Uzun, and A. D. Francia. 2016. Effect of group size and maize silage dietary levels on behaviour, health, carcass and meat quality of Mediterranean buffaloes. Animal 10:531-538. https://doi.org/ $10.1017 /$ S1751731115002359.

Moroni, P., C. S. Rossi, G. Pisoni, V. Bronzo, B. Castiglioni, and P. J. Boettcher. 2006. Relationships between somatic cell count and intramammary infection in buffaloes. J. Dairy Sci. 89:998-1003. https://doi.org/10.3168/jds.S0022-0302(06)72165-8.

Napolitano, F., G. De Rosa, F. Grasso, C. Pacelli, and A. Bordi. 2004 Influence of space allowance on the welfare of weaned buffalo ( $B u b$ alus bubalis) calves. Livest. Prod. Sci. 86:117-124. https://doi.org/ 10.1016/S0301-6226(03)00148-9.

Rasmussen, M. D., M. Bjerring, P. Justesen, and L. Jepsen. 2002 Milk quality on Danish farms with automatic milking systems. J. Dairy Sci. 85:2869-2878. https://doi.org/10.3168/jds.S0022 -0302(02)74374-9.

Shoshani, E., and M. Chaffer. 2001. Robotic milking: A report of a field trial in Israel. Pages III-56-III-63 in The First North American Conference on Robotic Milking, Wageningen Pers, Wageningen, the Netherlands.

Smith, J. W., L. O. Ely, W. M. Graves, and W. D. Gilson. 2002. Effect of milking frequency on DHI performance measures. J. Dairy Sci. 85:3526-3533. https://doi.org/10.3168/jds.S0022-0302(02)74442 $-1$.

Speroni, M., G. Pirlo, and S. Lolli. 2006. Effect of automatic milking systems on milk yield in a hot environment. J. Dairy Sci. 89:46874693. https://doi.org/10.3168/jds.S0022-0302(06)72519-X.

Stelwagen, K. 2001. Effect of milking frequency on mammary functioning and shape of the lactation curve. J. Dairy Sci. 84:E204E211. https://doi.org/10.3168/jds.S0022-0302(01)70219-6.

Tangorra, F. M., S. Leonardi, V. Bronzo, N. Rota, and P. Moroni. 2017. Pre-milking mechanical teat stimulation and milking performance of dairy buffaloes in early lactation. J. Agric. Eng. 48:5355. https://doi.org/10.4081/jae.2017.606.

Thomas, C. S., K. Svennersten-Sjaunja, M. R. Bhosrekar, and R. M. Bruckmaier. 2004. Mammary cisternal size, cisternal milk and milk ejection in Murrah buffaloes. J. Dairy Res. 71:162-168. https://doi .org/10.1017/S0022029904000081.

Wade, K. M., M. Van Asseldonk, P. B. M. Berentsen, W. Ouweltjes, and H. Hogeveen. 2004. Economic efficiency of automatic milking systems with specific emphasis on increases in milk production. Pages 62-67 in Automatic Milking: A Better Understanding. Wageningen Acad. Publ., Wageningen, the Netherlands.

Wagner-Storch, A. M., and R. W. Palmer. 2003. Feeding behavior, milking behavior, and milk yields of cows milked in a parlor versus an automatic milking system. J. Dairy Sci. 86:1494-1502. https:// doi.org/10.3168/jds.S0022-0302(03)73735-7.

Wall, E. H., and T. B. McFadden. 2007. Optimal timing and duration of unilateral frequent milking during early lactation of dairy cows. J. Dairy Sci. 90:5042-5048. https://doi.org/10.3168/jds.2007 $-0356$.

Zicarelli, L. 1997. Reproductive seasonality in buffalo. Pages 167-188 in Third Course on Biotechnology of Reproduction in Buffaloes, Caserta, Italy. Bubalus Bubalis S.r.l., Salerno, Italy. 